\title{
Time is Running Out: A Corpus Based-Study on Javanese Metaphors of Time
}

\author{
D Rahmawanto $^{1}$ and T Suhardijanto ${ }^{2}$ \\ \{1dwirahmawanto@ui.ac.id, 2totok.suhardijanto@ui.ac.id\} \\ ${ }^{1}$ Javanese Studies Department, ${ }^{2}$ Indonesian Studies Department \\ Faculty of Humanities
}

\begin{abstract}
Every culture in the world has its own ways to adapt against the challenges in their environments. In the process of adaption, people think and do whatever necessary for their survival. One of the many ways to be adaptive to the environment is to interpret or to give meaning to it. In this case, people often think it metaphorically or use metaphors to understand it. A metaphor is a way to understand and experience one kind of thing in terms of another. Like other people, Javanese people also use metaphor to understand and experience their life. This study deals with how Javanese people interpret and give meaning to time. It is interesting to explore how Javanese people think about time, because they do not recognize tense in their grammar. To this end, this study employs a corpus method by building a one-million-word corpus consisting of Javanese fictional articles, short stories, and novels. Three time-related words become the focus of the study, namely wanci, wayah, and wektu. The analysis shows that wanci and wayah have similar characteristics as they both indicate time as a static entity. Wektu, on the other hand, indicates time as a dynamic entity.
\end{abstract}

Keywords: conceptual metaphor, time, corpus-based study, Javanese

\section{Introduction}

Culture changes along with human life. Life challenges have made people adapt to their world. In this adaptation process, it is very common that people think and struggle to ensure their convenient life and survival. Human thoughts and efforts are somehow influenced by his/her environment. When the environment changes, some adjustment should be made in response. These process keeps on going as long as human exists and lives in the world. As [1] argues, human civilization grows from time to time and is connected in a spherical way.

Humans' thoughts and efforts to anticipate life challenges in their life are, among others, recorded into languages, especially in terms of how people think and express their thoughts using language. About this, [2] mention that the way people use language represents the way they live their life and reality. In other words, language can represent how people interpret their surrounding world.

Metaphor represents how a language speaker views their life and reality. As mentioned by [3], a metaphor is a way of understanding and experiencing one kind of thing in terms of another. Therefore, metaphor allows someone to thinks in an analogical way, that is, 
associating a concept of reality to another reality. In this association, a speaker thinks and then interprets a concept based his/her experience relating to a certain reality, then classifies such a concept based on its similarity to another concept that will be used as the vehicle in the metaphorical thinking.

Approach to metaphors is different from the traditional linguistic approach [3]. Under the perspective of cognitive linguistics, [3] views metaphors as a representation of a universal quality of thinking. In cognitive framework, a conceptual metaphor belongs not only to the language, but also to the way of thinking. Therefore, in the conceptual metaphor theory (CMT), conceptual metaphor represents the interaction between two domains, namely the source domain and the target domain. These structures are analogous to Richard's tenor and vehicle. In CMT, metaphorical mapping occurs between these two domains.

There are several studies of metaphors in Javanese cultures that have been conducted so far. [4] for instance, studies conceptual metaphors used in Javanese proverbs to reveal the local wisdoms in Javanese culture. Both [5] and [6] explore emotion metaphors in Javanese daily conversations under the cognitive linguistics analytical framework. Another study that focuses on Javanese emotion metaphors is conducted by [7], that analyzes some metaphors of affect in several languages - including Javanese and Balinese - to uncover the difference in the way of thinking among cultures. Javanese metaphor is also approached using morphological approach in [8], that explores morphological processes of Javanese metaphors in payandra - a specific discourse used for delivering Javanese wisdoms. [9] digs the use of sexual metaphors in two different political regimes in Indonesia, namely Soekarno' era and Suharto's era. [10] uses discourse analytic approach to analyze the structure of cohesion and coherence in Javanese metaphors.

For Javanese people, metaphor is not only about language, but also part of their culture. As a phenomenon, metaphor also attracts the interest of scholars from other fields. [11] for instance, studies metaphors used in Javanese wedding ceremony. Metaphor even becomes an object of ethnomusicological studies such as the ones conducted by [12], that studies metaphor used in Javanese singing, and [13], that studies Javanese gamelan to reveal how metaphors are used in music performances.

This study aims to explore time-related metaphors used in Javanese fiction. The fiction here includes all narratives and fictional writings such as short stories and magazine-published fictional writings. To accomplish a conclusive result, this study only focuses on three words that indicate time, namely wanci, wektu, and wayah (all meaning "time"), so as to reveal how Javanese people regard and view time in their daily life.

\section{Research Method}

A mixed-method approach is employed to answer the research question in this study. The quantitative method is used to depict the tendency and distribution of the data, while the qualitative analysis is performed a detailed way to find and establish a better understanding of how Javanese people look at and behave toward time. The data used were collected from works of literature and other fictional writings during the project of Javanese Corpus Building in Universitas Indonesia from 2016 to 2019. This corpus consists of 1,01 million words taken from 57 different sources, which are purposively selected to represent the language used in Javanese literature. To process the corpus, a tool called Lancsbox [14] is used. 


\section{Results And Discussion}

From the analysis, it is found that the use of words wayah, wanci, and wektu has several interesting points. In the Javanese Corpus, these three words appear with different frequencies.

Table 1 Word Distribution in the Javanese Corpus

\begin{tabular}{lc}
\hline Word & Frequency \\
\hline Wektu & 285 \\
Wayah & 99 \\
Wanci & 17 \\
\hline
\end{tabular}

Table 1 shows that the word wektu appears more often than wayah and wanci. It implies two cluster of meanings that differ wektu from wayah-wanci. The difference of word frequency between the two clusters indicates that Javanese people categorize the three words into two groups. According to the analysis result, the word wektu metaphorically associates to dynamicity, while wanci and wayah deal with staticity, as exemplified as follows.

\begin{tabular}{|c|c|c|}
\hline No. & Source Text & Example \\
\hline 1 & $\begin{array}{c}\text { Antologi wiring } \\
\text { kuning trinil }\end{array}$ & $\begin{array}{l}\text { langen asmara. Alesanku merga aku ora duwe", "wektu,","merga aku kudu } \\
\text { cepet cepet budhal kanggo" } \\
\text { (love letters. The reason is I do not have a much time because I need to go } \\
\text { immediately for ...') }\end{array}$ \\
\hline 2 & Djaka lodang & $\begin{array}{l}\text { Serikat (AS) apadene tentara Rusia, ananging tekan", "wektu", "iki cacahe } \\
\text { milisi Negara Islam ing Irak" } \\
\text { (... US and also Russian troops, but up to this time numbers of ISIS militia } \\
\text { in Iraq ...) }\end{array}$ \\
\hline 3 & Djaka Lodang & $\begin{array}{l}\text { nyilih dhuwit karo Santosa Rp.500.000 lan menehi", "wektu","1 jam. } \\
\text { Santosa nyaguhi bakal kirim dhuwit" } \\
\text { (... borrowed Rp500.000 from Santosa and gave me an hour. Santosa } \\
\text { promised to send the money to ...) }\end{array}$ \\
\hline 4 & Kinanti & $\begin{array}{l}\text { dawa. Nyawang peturonku kang wus lawas dipangan", "wektu","tansah } \\
\text { adhem. Aku lan Yulia kaya dene" } \\
\text { (... long. Looking at my old bed which is ruined, it is always comfortable. I } \\
\text { and Yulia like ... ) }\end{array}$ \\
\hline 5 & $\begin{array}{c}\text { Lelakone Si Lan } \\
\text { Man }\end{array}$ & $\begin{array}{l}\text { ","mbarek Mawestri iki gak terganggu sak dawa- } \\
\text { dawane", "wektu.", "Srengene ebes lan gegere emes bantahane dipekir" } \\
\text { (... with Mawestri it is not annoyed by the length of time being. Father's } \\
\text { grin and mother's anger, I just don't care ...) }\end{array}$ \\
\hline
\end{tabular}

The above table lists sentences that use the word wektu. From the words that accompany $w e k t u$, it is seen how the speaker views wektu in the Javanese language. From those sentences, the word wektu is seen variedly by the speakers. In sentence 1 and 3 , it is seen as a commodity that one can own and give like money (ora duwe dhuwit 'does not have any money'), a car (ora duwe montor 'does not have any car'), and a house (ora duwe omah 'does not have any house'). Wektu as an abstract object that cannot be perceived by human senses is used as if it is a concrete thing that can be touched and transferred.

Besides, wektu is also seen as a track or course where people make a journey. In sentence 2 , for instance, it is seen as a point in someone's journey, as indicated by the word tekan "arrive" that accompanies it. The use of the word tekan shows that wektu is seen as a point where someone stops their journey, like a house (tekan omah 'arrived at home'), a market 
(tekan pasar 'arrived at the market'), and a certain region like Surakarta (tekan Surakarta 'arrived in Surakarta').

The word wektu is also seen as an animate object that can perform actions like eating, as seen in the fourth sentence. Syntactically, in sentence 4, the word wektu has the role as the agent of the action pangan 'eating'). It is personified as if it can eat the object paturonku kang wis lawas 'my old bed'.

In sentence 5, the word wektu is seen as an object that has lengths, as indicated by the accompanying word sakdawa-dawane 'the length'. The word dawa 'long' indicates the existence of a unit of length that stretches from one point to another. The use of construction sakdawa-dawane wektu 'the length of time' illustrates wektu as object with length units like a wood pole (genter dawa 'a long wood pole'), a rope (tali dawa 'a long rope'), and yarn (benang dawa 'a long yarn').

The above elaboration shows that the word wektu is seen variedly by the Javanese people. Wektu is perceived as a dynamic object that can move from one pace to another and do actions. Additionally, time is also seen as something static, such as a course for someone to walk on.

Unlike wektu, wayah and wanci appear in a lesser frequency. The word wayah and wanci are rarely used because such words are associated as static objects. This is seen in the words that accompany them in the following sentences.

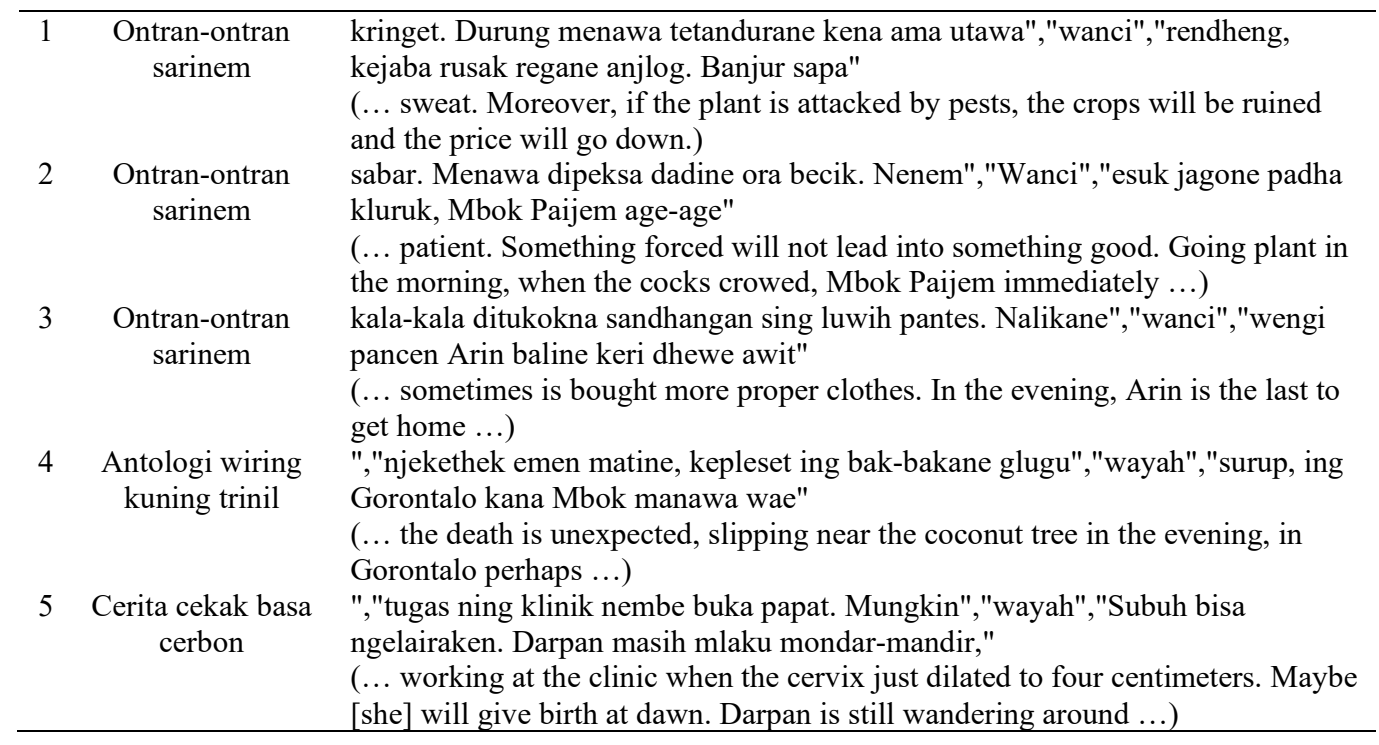

From the above table, it is seen that the words wayah and wanci are often accompanied by words like wengi 'evening", rendheng 'rain season', surup 'twilight', and subuh 'dawn'. Such words refer to the natural phenomena when the sun is in a certain position. The word wengi, for instance, refers to the time when the sun has completely set. The word surup refers to the time when the sun just set but its light still shines a little. The word rendheng, on the other hand, refers to the season when the rainfall is high. From these words, it is known that wayah and wanci tend to be used to refer to certain natural conditions. They are seen as something static, because basically the nature where Javanese speakers live have been created before. These words are seen as a big space with various phenomena where human live. 
In this sense, Javanese people will always experience certain points such as the sunset, the dawn, and so on. It also shows that wektu and wayah are seen as a course that human can explore. The sentence nanging besuk teka titi wanci laire anakku mbarep, aku ora bisa nunggoni 'but in the future when the time is come for my first child to be born, I will not be able to stand by their side' indicates that the word wanci can be accompanied by the words teka 'come/arrive'. The construction teka titi wanci anakku mbarep lair is used as an illustration that the speaker is walking on a course and arrives (teka) at a point where his first child is born (laire anakku mbarep).

Javanese people perceive wayah and wanci as a static entity, as seen by how these words are never used together with words like menehi 'to give' (*menehi wayah/wanci), dipangan 'to be eaten' (*dipangan wayah/wanci), and nduwe 'to have' (*nduwe wayah/wanci). In other words, wayah and wanci are not seen as animate objects that can do actions or move from one place to another.

\section{Conclusion}

Javanese people express the concept of time through the words wektu, wayah, and wanci. Although all of them refer to the same concept, they are used differently, which indicate the perspective of Javanese people on time. The time expressed through the word wektu is seen as something that may be static and dynamic. As something dynamic, the word wektu is treated as an animate object that can do some actions and move from one point to another. On the other hand, as something static, the word wektu is illustrated as a track or course for human to walk on. Unlike wektu, the word wayah and wanci express time as a static entity that refers to natural phenomena.

\section{References}

[1] F. X. Rahyono, Bahasa dalam Kebudayaan Jawa. Jakarta: Wedatama Widya Sastra, 2015.

[2] B. L. Whorf, Language, Thought, and Reality. Cambrigde: The MIT Press, 1956.

[3] G. Lakoff and M. Johnson, Metaphors We Live By. Chicago: University of Chicago Press, 1980.

[4] D. Nirmala, "Local wisdom in Javanese proverbs (a cognitive linguistic approach)," in International Seminar on Language Maintenance and Shift 3, 2013, pp. 124-128.

[5] E. Rahardian, "Metafora emosi dalam tuturan bahasa Jawa," Universitas Diponegoro, 2017.

[6] E. Rahardian and D. Nirmala, "The Force Scheme in Javanese Emotion Metaphors," Parol. J. Linguist. Educ., vol. 8, no. 1, pp. 12-18, 2018.

[7] L. E. Crawford, "Conceptual metaphors of affect," Emot. Rev., vol. 1, no. 2, pp. 129-139, 2009.

[8] D. A. W. Nurhayati, "Investigating morphological process of payandra on Javanese metaphor," J. English Lang. Teach. Linguist., vol. 1, no. 3, pp. 245-259, 2016.

[9] S. E. Wieringa, "Sexual metaphors in the change from Soekarno's Old Order to Soeharto's New Order in Indonesia," RIMA Rev. Indones. Malaysian Aff., vol. 32, no. 2, p. 143, 1998.

[10] A. Wahab, Javanese Metaphors in Discourse Analysis. Indonesia, 1987.

[11] I. Arvianti, "Metafora Tuwuhan Dalam Budaya Pernikahan Adat Jawa," Majalah Ilmiah INFORMATIKA, 2016.

[12] M. Benamou, "Of Zebra Doves and Prawn Crackers: Javanese Metaphors for Vocal Types," Phenom. Sing., vol. 1, pp. 25-32, 2013.

[13] I. Becker, "Earth, fire, Sakti, and the Javanese gamelan," Ethnomusicology, pp. 385-391, 2016.

[14] V. Brezina, M. Timperley, and T. McEnery, "\#LancsBox v. 4.x [software]." 2018. 